\title{
Reducing Polarisation in the World
}

\author{
Abdul Karim Abdullah *
}

There are wars happening in Syria, Iraq, Afghanistan, and Yemen. A million Muslims have died in Afghanistan. Another million Muslims are reported to have died in Iraq. More people are dying and being displaced in Syria, and Yemen.

After the demise of the caliphate in 1924, it appears that polarisation between Muslims and non-Muslims is getting worse. The clash of civilisations is fast becoming a grim reality. Even the polarisation between Muslims is not decreasing.

The Qur'an states, "Invite (all) to the Way of thy Lord with wisdom and beautiful preaching; and argue with them in ways that are best and most gracious: for thy Lord knoweth best, who have strayed from His Path, and who receive guidance." (16:125)

Radical factions have been wreaking havoc. They have arrogated to themselves the right to 'interpret' Islam for all. Yet what presents itself as an 'interpretation' is, more often than not, a misinterpretation.

Radical fringes display hatred of people whose main fault is being different. It is important to restrain extremists before they perpetrate greater damage and injury. Problematic preconceptions, for example the binary division of the world into a realm of peace (Islam) and an abode of war (everywhere else), are used.

The Arab Spring promised change for the better. Instead it brought misery and destruction. In Egypt, the Morsi government alienated significant parts of the population with its erratic behaviour. When it tried to pursue retribution against the military, its nemesis took over. By contrast, the attempted uprising against authorities in Turkey failed. Both nations now find themselves at different ends of the political spectrum. Hopefully, they will get nearer rather than drift further apart.

In Europe, the political temperature is rising. Xenophobic, nationalistic parties are registering growing support. The ill-wishers and enemies of Islam are pleased to see this happen, as it serves their interests.

It appears that ISIS initially received Western backing in the hope that they would turn against the Syrian regime. When ISIS instead began beheading Western prisoners and its enemies in Syria and Iraq, it became difficult to support ISIS.

Another reason for misunderstandings is that different people see Islam differently. The discourse of jihadism falsifies Islam. There is a need for a better understanding. 
The way to reduce polarisation is to focus upon what Muslims share (the Qur'an) rather than where differences arise (divergent explanations of what transpired in the past). In this way, the Muslim ummah should be able to recapture the universal understanding of Islam and address the deep problems it is now facing. What is required is to follow the middle path of wasatiyyah or moderation.

Political Islam has brought greater harm than benefit. It needs to be recalled that there is no exhortation in the Qur'an to establish an "Islamic state." The primary task of the Prophet Muhammad was to spread a message of peace. Islam and Islamism are two different things. Islam is a way of life, not a political teaching.

There is excessive focus on externalities and insufficient emphasis on substance. People are too concerned with the way people dress rather than with how to alleviate poverty, reduce ignorance, and enhance good governance and people's welfare.

It is important for Muslim institutions of learning to emphasise thinking. After all, the protection of the intellect ( $a q l$ ) is among the chief purposes of the Shari'ah. There can be little progress without a thoughtful approach. Exchanges of views can help reach common ground on important issues.

There is a need for a rational approach. Extremists denigrate reason, as to do so helps them maintain their sway over fanatical followers. The Qur'an states, "Surely the worst of beasts in God's sight are those that are deaf and dumb and do not reason." (8:22). Elsewhere, it states "And it is not for a soul to believe except by permission of Allah, and He will place defilement upon those who will not use reason." (10:100).

In the final analysis, it needs to be recalled that the "pen is mightier than the sword." The Qur'an states, "Allah does not change the condition of a people until they change their own condition..." (13:11) The right way to defend Islam is by explaining it properly, including its higher purposes. At the same time, it is important to follow up with excellent behaviour.

\section{Notes}

* Abdul Karim Abdullah is a Research Fellow at IAIS Malaysia. He may be reached at abdulkarim@iais.org.my. 